\title{
THE NATIONAL COMMITMENT TOWARDS CONSERVING THE HERITAGE (DOCUMENTATION OF HISTORICAL AND CULTURAL SITES IN GCC COUNTRIES)
}

\author{
Dr.Fatema AlSulaiti \\ fatemaalsulaiti@moqarnasat.com \\ http://www.moqarnasat.com/
}

KEY WORDS: Gulf countries, Documentation, Cultural Heritage Management Plan, al-Zubarah-Qatar

\begin{abstract}
:
The five Arab Gulf countries of Kuwait, Bahrain, Qatar, the United Arab Emirates and Oman possess many shared characteristics and historical ties across their common peninsula. The prime factor uniting them is the historical nature of their entwined involvement with peoples and nations beyond the region. That the Gulf has been an important water passageway since ancient times suggests that the inhabitants of its shores met early on with other civilizations.

The knowledge of one's roots, history, and traditional arts supports awareness of inherited culture and can help contextualize and illuminate community reflection and identification.

The intricacy of the recording and understanding processes of documentation requires skilled professionals, with knowledge and awareness for the associated tasks.

Responsible of cultural heritage should provide the adequate documentations, recording and updating of the records. Collaboration of different individuals such as specialist heritage, archaeologists, surveyors, conservators, researchers, architectural historians, and many other expert personnel is the golden key of successful documentation.

The purpose of this document is to show the authorities of Gulf Arab countries and their planning measures, management and sharing effect of recording the cultural heritage. This essay identifies key points in the approach to contextualizing and developing cultural identity in a way that respects organic qualities. Through highlighting a number of archeological ruins and outlining management plans, the essay explores frameworks that can be applied to promote and preserve integral identity of important sites and their greater surrounding communities.
\end{abstract}

\section{INTRODUCTION}

The five Arab Gulf countries of Kuwait, Bahrain, Qatar, the United Arab Emirates and Oman possess many shared characteristics and historical ties across their common peninsula. The prime factor uniting them is the historical nature of their entwined involvement with peoples and nations beyond the region. That the Gulf has been an important water passageway since ancient times suggests that the inhabitants of its shores met early on with other civilizations.

The knowledge of one's roots, history, and traditional arts supports awareness of inherited culture and can help contextualize and illuminate community reflection and identification.

This essay identifies key points in the approach to contextualizing and developing cultural identity in a way that respects organic qualities. Through highlighting a number of archeological ruins and outlining management plans, the essay explores frameworks that can be applied to promote and preserve integral identity of important sites and their greater surrounding communities.

\section{KEY POINTS FOR REINFORCING ORGANIC CULTURAL IDENTITY}

A number of elements are essential in creating a sound foundation that fosters strong sense of place in past, present, and future. Various tools such as artistic and cultural inventories and records allow a community to understand its historic, cultural, economic, and social faces. In concert, a creative community vision which is open to continuous evolution and new ideas can simultaneously balance the inherent, and perhaps conflicting, nature of past with present and future community values and cultural characteristics. Such a vision must simultaneously reinforce and embrace the changing climate, as well as the local content and body of a place developed organically over time.

\subsection{Understanding Community Context: Documentation in Saudi Arabia}

Supporting a community's self-image and recognition of its historic, cultural, economic, and social contexts is an essential foundation for developing and building sense of place. An important contribution to community image, and perhaps a first step in unfolding community discovery, is a reading and inventory of place.

Inventory includes the identification, assessment, and mapping of a community's artistic and cultural resources. In a way, it is a guided visioning exercise that can engage residents in an interactive and creative process of developing a vision for future communal arrangement. Inventory opens access to various shades of community self-contextualization and can foster the emergence of community voice in weaving its own narrative.

Relevant mapping elements span population, demographic, and linguistic characteristics; physical and natural resources; cultural history; climate; customs; landscape features; design and architectural elements; local educational institutions; public works and space projects; and art and cultural exhibitions and events. Inventory components may include the following:

- Population and demographic information 
- Local social and architectural history

- Languages and dialects spoken

- Food culture

- Unique customs

- Current landscape

- Scale of existing buildings (residential, commercial, governmental and institutional buildings)

- Public spaces

- Transportation infrastructure

- Temporary markets and fairs

- $\quad$ Patterns, colors, and materials of buildings

- Natural resources

- Native plants

- Street, business, and community signage

- Art forms

- Local educational institutions (colleges, universities, etc.)

- $\quad$ Art institutions (museums, galleries, theaters, historic homes, etc.)

An example highlighting the contextualization of community character against a historically significant backdrop is the preIslamic archaeological site of Madâin Sâlih.

Madâin Sâlih, al-Hijr, Saudi Arabia: Treasure in the Arabian Desert. Madâin Sâlih was the first World Heritage property to be inscribed in Saudi Arabia in 2008. An archaeological site, the largest conserved of the Nabataean civilization, Madâin Sâlih was an ancient oasis. The water of this oasis was provided by 130 wells dug into bedrock, which were fed naturally by contact with the watertable. All of the wells were likely associated with farming and cultivated areas, making the ancient site of al-Hijr an agriculture production center.

The now far isolated city was once a vibrant center of trade, agricultural land and oasis, and the al-Hijr site presents an important interchange of human values accumulated over a long period of time. It is a crossroads of several civilizations and trade routes linking the Arabian Peninsula with the Mediterranean World and Asia.

Showing a fusion of mixed cultural traditions, its importance as a site of inter-civilizational and ethnic interchange appears clearly in both its architectural styles and in the variety of languages and scripts found in markings and inscriptions at the site.

In the face of challenges of preserving an ancient pre-Islamic site, official protection of Madâin Sâlih is codified in law and the specific religio-historic identity of the site has in fact kept many local inhabitants away. A sentiment held among many Saudis that the site is cursed, reflecting a reference in the Qur'an, has indirectly aided preservation of the site in the past since its use as a residential area has been shunned by local bedouins and farmers.

The al-'Ulâ Municipality in Medina al-Munawarra prepared a regional plan in 2012 by setting development guidelines for the city through the year 2030. Following, a management plan was proposed by foreign consultants and the Supreme Commission for Tourism. Some of the following points within the plan are currently being implemented, while others remain at the level of hypotheses and suggestion.

- Planning of the surrounding areas and of the access routes to the site, including proper signage.

- Identification of the most suitable conservation and restoration techniques for the site in the full order of international best practices and international restoration charters.
- Definition of a set of priority interventions to be carried out for the conservation of the site, both in its architectural elements and landscape. The definition of 'priority' will result from the preparation of a site 'Risk Map' analyzing the present situation and identifying needs and priorities.

- Tourism management and the handling of visitors to the site. The main points to address are: the definition of tourist circulation and special circuits, creation of services (cafeteria, restroom, first aid, shops, and boutiques, etc.), enhancement of the quality of the visit (considering fluxes, circulation, explanatory panels and visitors' centers, guided tours, publications, etc.), visitor security, and onsite protection from visitor impact.

- Control and management of foreign and national archaeological missions excavating at the site. Accent should be placed on the conservation and presentation of the sites during and after the excavations.

- Tourist development of the site through the reorganization of access (shift from the South entrance to the North Gate), the careful landscaping of the access area, the planning of soft cultural activities (in the Ottoman Fort and in the area in front of it), the creation of a visitors' center, a Hijâz Railway exhibition, special site riding tours (horseback or camelback) and discovery tours to the nearby archaeological sites.

- The management (in close collaboration with the overall SCT program) of marketing activities and the development of a site 'brand image' through national and international advertisement campaigns, based on al-Hijr's inscription on the World heritage List.

- Management of the economic resources generated by site development, and integration of local and national entrepreneurial activity into a sustainable development strategy focusing on site preservation.

- Development of the site's legal protective system through a monitoring of the respect of the norms established for the buffer zone (and possibly, if the National Cultural Heritage Park will be created, beyond this zone). Additionally still, through public relation campaigns specifically aimed at local communities (schools, municipalities, associations and provincial bodies). Campaigns would be designed to strengthen local community bond with the site and aim at developing local awareness of the global significance of the site, its scientific and cultural heritage value to the Kingdom of Saudi Arabia and its people.

- Administration and the training of site employees and site management teams through on-site training programs.

\subsection{Reinforcing Sense of Place: Documentation in Bahrain and Oman}

While an inventory of physical space and domain provides the initial context for constructing place, the characteristic climate over time is also necessary to more deeply create live community identity. Identity therefore requires a comprehensive understanding of a community's cultural, economic, and social contexts in both past and present.

Moreover, melding physical identity and organic identity needs a vision for the future that continuously evolves and embraces new ideas while balancing the inherent conflicting nature of past, present, and future community values and characteristic.

Community character is that which a community has inherited over a time continuum and is not that which can be superficially applied or imposed. The multiple facets of character are conveyed not only by grand buildings and public spaces, but by a great 
range of urban elements: residences of all sizes and scales; commercial, government, and institutional buildings; street crosssections; street furniture and graphics; public places, large and small; ceremonial buildings; informal installments such as street markets and fairs; and the food, language, and personalities that contribute to a community's narrative.

Only through the understanding and reinforcement of its character can a community flourish in civil, social, and economic spheres. Planners are uniquely qualified to guide citizens in this process of discovery, appreciation, and celebration of community character.

Qal'at al-Bahrain (Fort), Bahrain: The Port of Paradise. The 1954 finding of the Dilmun civilization in Bahrain was a highly significant archaeological discovery on both regional and international levels, as it turned up the first concrete archaeological evidence of the Dilmun, which had, until then, been considered a historical and philological concept. One of the great civilizations of the ancient near east, the Dilmun is spoken of together with the civilizations of the Tigris and Euphrates Valley, the Nile Valley, the Indus Valley, as well as ancient Persia.

From the first excavations in 1954 by the Danish Archaeological Mission to Bahrain under Dr. Geoffrey Bibby, as well as Professor P.V. Glob (both helped found the Bahrain Historical and Archaeological Society), the site revealed an impressive stone palatial architecture and distinctive pottery productions - the first specimens of the now famous Dilmun stamp seals.

The palaces of Dilmun - unique examples of public architecture from the civilization and period-also influenced architecture within the wider region. The fortifications are among the best examples of defensive structures from the $3^{\text {rd }}$ century BC through the $16^{\text {th }}$ century AD. The protected palm groves surrounding the site are characteristic of the landscape and agriculture of the region at an early time.

Qal'at al-Bahrain, or the fort of Bahrain, was built in the $14^{\text {th }}$ century and was utilized by the Portuguese until the $16^{\text {th }}$ century. The fort spreads across 17.5 hectares on an artificial hill built up over 4,000 plus years of continuous human occupation. The site is the former capital of the Dilmun civilization and one of the most significant archaeological sites in the Kingdom of Bahrain. Excavations have revealed residential, public, commercial, religious, and military structures which testify to the importance of the site lasting through centuries.

Archaeological work conducted at the site over the past fifty years which has revealed an almost continuous stratigraphy from ca. $2300 \mathrm{BC}$ to the $16^{\text {th }}$ century $\mathrm{AD}$, with the exception of some yet enigmatic gaps in the old Babylonian (ca. 1700-1450 BC) and Early Islamic periods $\left(6^{\text {th }}\right.$ to $13^{\text {th }}$ centuries AD).

During most phases of its development, the city of Qal'at alBahrain was marked off at the heart of the fertile zone by a rampart (which appears today to have stood for almost two millennia), several public buildings for economic, administrative, or religious use (in the Bronze Age as in the Iron Age), and a rare military and defensive architectural tradition (dating back to the beginning of the Christian era).

All of these particular features, unique to Bahrain, evoke an image from the past of a thriving cosmopolitan merchant city playing an essential role as a staging post and trade center between Mesopotamia, Persia, Arabia, Oman, the Indian subcontinent, and even the Far East. The key role occupied by Qal'at al-Bahrain during the regional development of the Dilmun civilization contextualizes its great significance regionally and beyond.

Management Plan. The Ministry of Culture of the Kingdom of Bahrain, the management authority of Qal'at al-Bahrain, submitted a site management plan in 2003 that outlines a longterm legislative, regulatory, and institutional framework for site preservation. Technical experts remain in contact with site managers in their capacity of advising on and helping to bring the actualization of restorative efforts in the near future, principally on the main fortress. Such technical expertise is needed to oversee builders in best restorative and preservation efforts; although trained in traditional workmanship practices and with knowledge of local materials, technical know-how regarding various conservation mechanisms, levels of intervention, and issues of authenticity appears insufficient. The management plan aims to establish a solid team of experts for solid site specific preservation.

The site is presently accessible by road and houses a visitor's center with museum, posted signboards for description and interpretation, a cafeteria, public rest facilities, and general information available in written pamphlet form.

Qal'at Bahla Fort, Oman: A Fortified Sanctuary. Bahla is an eminent example of a fortified oasis settlement of the medieval Islamic period, exhibiting the water engineering skill of its early inhabitants for agricultural and domestic purposes.

The fort, designed before the advent of gunpowder, with rounded towers, crenellations on parapets, and a perimeter wall of stone and mud brick, demonstrates the status and wider influence of those who comprised the ruling elite.

The remaining mud brick family compounds of traditional vernacular houses (harats) including al-Aqr, al-Ghuzeili, alHawulya, and the associated mosques, audience halls (sablas), bath houses, together with the dwellings of the fort guards (askari), reveal a distinctive settlement pattern related to the location of an underground system of aqueducts, or falaj. The importance of the settlement is enhanced by the standing mosque, with its highly ornate mihrab, and the remains of the old, semicovered market (souq) comprising a complex of single-storey shops fronting narrow lanes-the whole enclosed by an outer wall. The location of the souq placed it within easy surveillance from the fort on its rocky outcrop nearby. Remains of carved and decoratively incised timber doors, shelves and window screens testify to a rich, thriving craft tradition.

The Bahla Fort and oasis settlement, with its perimeter fortification, is an impressive example of a defensive architectural ensemble that enabled dominant tribes to achieve prosperity in Oman and the Arabian Peninsula during the late medieval period.

\subsection{Local Implementation Framework: Documentation in UAE}

Artistic and cultural inventories and programming, educational and cultural institutions, community visioning processes, master plans, and public financial investment in urban design and place making are all important elements of an overarching strategy that planners can use to explore community context, embrace and nurture community diversity and uniqueness, and build upon and celebrate community character. All of these components serve as a network of origin and support for cultural reflections and community member involvement, engaging citizens and deepening awareness of and interaction with surroundings. 
Preserving and enhancing unique local identity, and arts and culture assets of a community require that local decision-making, planning processes, policies, and regulations reflect and support this community character. Local government programs, policies, and regulations that incorporate the underlying philosophy or identity of a community can provide a framework for decisionmaking, encourage development that is place-based, and reinforce the cultural goals and vision of a community. Frameworks which heed these guidelines and concerns cane support the work of civic leaders and community advocates, and can help bring new allies, talent, and ideas into the planning process.

Public Art Master Plans. Public art-such as historical monuments, sculptures, mosaics and decorative features-is an important element in place making. Public art work is ideally sitespecific and attuned to their social, economic and environmental contexts - capable of contributing to urban design and the revitalization of civic infrastructure, enhancing and personalizing public space, commenting on environmental and social conditions, and activating civic dialogue.

The development and adoption of a public art master plan provides an opportunity to establish a shared vision for a community's public realm and coordinate the activities of multiple stakeholders (planners, artists, arts and culture-related nonprofit organizations, and other stakeholders) in shaping that realm. Increasingly, communities around the world are developing and adopting public art master plans for the purpose of demonstrating a long-term commitment to the central importance of public art in the planning, design, and creation of public space.

Public Investment in Urban Infrastructure . Urban infrastructure design reflected in architecture, streetscapes, and transportation facilities, presents opportunities to interpret the multitude constituent elements of place. Through the creative development streetscape design, transit facilities, street signage, and other elements of infrastructure, artists can inform, educate, and comment on these local conditions.

Qal'at al-Jahili, al-'Ain, Abu Dhabi: A Symbol of Traditional Architecture. Al-Jahili fort in al-'Ain City is a significant landmark that symbolizes the traditional architecture and cultural heritage of the United Arab Emirates.

The cultural sites of Hafit, Hili, Bidaa Bint Saud and oasis areas are situated in al-'Ain City, the capital of the eastern region of the Emirate of Abu Dhabi, United Arab Emirates. These sites represent a culture that has evolved over time, and was earlier characterized by its ability to overcome the challenges and limitations of a harsh natural environment. Facing scarce resources, cultural development grew organically and responded with unique achievements at the level of human subsistence, agriculture and irrigation, long-distance trade, cross-community relationships, architecture and funerary traditions. Perhaps the most impressive mark of cultural character here has been the capacity to continually re-invent, recreating the elements of its sustainability.

Adjacent to al-'Ain Oasis is the fort of Qal'at al-Jahili, likely erected to ensure the security and integrity of the oasis. The construction of several forts-Jahili, Mezyad, and Sultan, as well as the large enclosure known as Muwaiji Palace-ensued at the end of the nineteenth century under Sheikh Zayid I. As the ruler of Abu Dhabi, he consolidated power over al-Ain through this building campaign between 1887-1891.
Al-Jahili is located in al-'Ain's city center next to the Jahili Public Gardens in the west of al-'Ain Oasis. The Jahili fort complex contains many individual elements of traditional mud brick architecture preserved in other parts of al-'Ain, including a round watchtower, a square fort with defensive towers at the corners, a larger enclosure wall, and a mosque outside the walls. Recent work has even uncovered the remains of a falaj, or a covered irrigation channel, which likely formed part of the public works carried out during the expansion of al-'Ain, accompanying the arrival of the an-Nahyan family at the end of the nineteenth century.

The significance of al-Jahili lies in its central location in modern al-'Ain and the survival within it of a large and imposing traditional building. Elements of this building provide a strong physical and visual link to significant local and regional events of both the nineteenth and twentieth centuries. The fort preserves important associations with the rise of the an-Nahyan family and Sheikh Zayid I, as well as the formative historical events of the region during the 1950 s, namely that of the Buraimi dispute of 1952-55 and the Jebel Akhdar war in Oman from 1954-59. Indeed, the location and landmark status of the site is such that alJahili Fort has come to symbolize the traditional architecture and cultural heritage of the UAE.

Management Plan. The site's preservation plan includes an impressive mechanism of climate control. The cooling system inside the building was created by combining new technologies with some of the oldest known to man. Mud brick, or adobe, is ideally suited for hot arid climates and has excellent insulation properties; it keeps the mid-day heat out and helps to equalize the experience of daytime and nighttime temperatures. This natural climate control was enhanced by embedding cold water pipes into the mud plaster of the walls, resulting in a comfortable sustained internal temperature of $22^{\circ} \mathrm{C}$. Additional cooling is provided by cold air ventilation controlled by intelligent sensors that minimize energy consumption. These innovations utilize novel and traditional technologies, helping to maintaining the fort's unchanged external appearance, while making adjustments and that meet the needs of its $21^{\text {st }}$ century guests.

At present, al-Jahili Fort is open to the public and houses a visitor's center, a permanent exhibition featuring explorer Wilfred Thesiger, a temporary exhibition space and other visitor facilities. An innovative audio-visual installation about the history and development of al-'Ain City was added in 2009, experienced as a 31-minute walk through of the fort's iconic round tower.

Landscape Design and Lighting: The Landmark of al-'Ain. The boundaries of the oasis' buffer zone are determined by the following factors: adjacent groups of buildings affecting the visual setting of and access to the oasis (where regulations on land use, height, and architectural design of buildings will be drafted with the support of al-'Ain Municipality and incorporated into the upcoming Local/Action Area Plans within the scope of the al-'Ain 2030 Framework Plan to prevent encroaching development. Further development will be suspended until new regulations are issued, and buildings that have reached the end of their lifespan will be replaced with landscaping or development, subject to new design guidelines and sightline considerations); adjacent lots of open land, whereby agricultural and green land usage will continued under regulation; adjacent historic landmarks that form natural extensions of the oasis setting; and lastly, land abutting 
nearby urban streets, forming reasonable thresholds when including the above-mentioned buildings.

Management Plan. A team of urban planners and designers, heritage, landscape, environmental, and institutional specialists was commissioned to prepare a World Heritage Site Management Plan for the Bahla Fort and Oasis Settlement.

The $13 \mathrm{~km}^{2}$ site is inscribed on the List of World Heritage in Danger due to the vulnerability of its many earthen structures, the rapid pace of modernization, inadequate planning controls, conservation, and maintenance, the disappearance and erosion of cultural heritage elements such as the abandonment of traditional vernacular houses, changes in materials and methods of construction, and hydrology problems stemming from the aquatic environment.The management plan combines elements found within the urban conservation plan created for the site, along with operational guidelines for the Bahla Fort specifically. The project is undertaken in accordance with a number of Abu Dhabi council and ministry and UNESCO requirements, international conservation charters, and principles of sustainable tourism. It is a three-stage process of research and investigation, evaluation and management strategies, and development of the site within its own cultural, social, and institutional contexts and following priorities of conservation and sustainable tourism.

\subsection{Arts and Culture Programming: Documentation in Qatar}

Arts and culture programming plays a crucial role in providing education about the historical and cultural context of a community. Programming creates opportunity for participation and exchange in communal life through festivals, performances, interactive classes, workshops, and a variety of other activities. Significantly, members are actively engaged and their contributions braided into the live fabric of their own community. Programming initiates conversation about arts and culture, and establishes a structure of plans that ensure these activities will continue to flourish. This deliberate continuity can help strengthen creative ideas, inspire citizens, and create important opportunities for participation.

Qal'at al-Zubarah, Qatar: Rebirth of the Middle East's Pearl Hub. Al-Zubarah is a 1.54 mile $^{2}$ site on the northwest shores of Qatar. The site comprises the old town, incorporating town walls, a port, a sea channel, and the two forts of al-Murair and alZubarah.

Al-Zubarah fort is an ideal example of an $18^{\text {th }}-19^{\text {th }}$ century Middle East pearling and fishing town, and one among a few cases in the region of a well-preserved historical site in which the entire urban layout dating back three centuries still remains intact. The town of al-Zubarah is considered a vital example demonstrating a transitional period in the region's history.

Excavation conducted at al-Murair fort revealed structural remains in good condition. A local souq, traditional houses, and fragments of a palatial complex were among the chief discoveries. Excavations at al-Zubarah shed light on its significance as an urban site of trade and economy from the late $18^{\text {th }}$ century, turning up materials such as pottery and ceramics, coinage, and diving weights whose origins were in East Asia, Africa, Europe, and the Gulf. Al-Zubarah also highlights elements of Qatar's early development and emergence.
A national conservation strategy emerged in Qatar in 2009, utilizing intensive methods of preservation. Careful and deliberate study of the architectural elements of al-Zubarah's monuments aided in the creation of the most suitable saline resistant mortar and plaster. These specially crafted construction materials provided the site the durability needed in preservation.

A master plan for construction of a visitor center has been drafted, and its eventual construction must be handled with the utmost care so as to avoid any potential damage to the integrity of the fort's setting and to the authenticity of its interior-where there is only limited potential for the installation of new facilities for visitors. Yet, there is room for consideration of a few additional elements using remaining spaces, such as including a craft exhibition centre.

The possibility of 'greening' the courtyard could be considered. Although there is no precedent for this in the fort's history, it is a powerful theme of Arabic architecture; the courtyard could serve as a final space reached at the end of one's visit, where educational information about the historical and cultural context of the Qatar community is distributed.

The fort's position also offers stunning views of the structures that make up the World Heritage Site. This position may suggest that the fort should either be designated as a launch point for visitation or as a final destination, the culmination of the site visit.

Management Plan. As the first site nominated and presented by the Qatari government to the UNESCO World Heritage Centre for inscription in the List of World Heritage Sites, al-Zubarah was added to the tentative list in 2008 and research and development has been ongoing since 2009. The site has the potential to become a model of sustainability and innovation for archaeological and cultural sites in Qatar.

The inscription of al-Zubarah archeological site represents the first and most crucial step towards the creation of a future heritage reserve, providing a counterpart to the modernity of the Qatari capital, Doha.

The management plan for al-Zubarah archeological site sets out to make substantial advances in archaeological and historical research findings, conservation, outreach, and tourism management, setting the standard for protection and administration of heritage sites in Qatar.

The management plan's prescriptions seek to uphold the "outstanding universal value" of the site and its presentation to the public in a substantially informative and sustainable manner. This is achieved through the implementation of a holistic organization, which aims to:

- Ensure appropriate use of the site and controlled development of the area

- Establish mechanisms for efficient coordination and collaboration among the parties responsible for protecting and presenting the site.

- Foster the capacity building process of the State of Qatar in relation to professional handling of heritage. This will be achieved by implementing a system for the protection and management of the site - subject to formalized control, which involves intensive training and education of local human resources.

- Introduce and implement sustainability as the leading principle in handling of the site in terms of research, conservation and presentation. This will enable the creation of a CO2-neutral, environmentally friendly heritage area 
showcasing sustainable development reliant on minimized waste of water and other natural resources.

- Offer to the site visitors a safe, informative and pleasurable experience.

- Increase research and disseminate knowledge and awareness of the cultural and natural history of the region in national and international contexts.

\section{Conclusion}

Archeological and culture strategies help to reveal and enhance the underlying identity of community, fostering its inherent character and the elements unique to it. Notions of identity are reflected through and cycle from sense of place, which is not a static concept but instead, evolves and develops over time and reflects the spectrum of social values within and around community.

In this way, the community character of a city, county, town, or neighborhood can be seen as a story and narrative of its place. Planners and community members can come together to reveal and burnish this narrative through an articulation of the historic, cultural, economic, and cultural context of the community; a commitment to the reinforcement and enhancement of the community's identity; and the implementation of policies, regulations, and incentives that support and enhance this evolving identity.

\section{Bibliography}

Reports for World Heritage UNESCO:

1-Al-Hijr Archaeological Site (MÂDAIN SÂLIH), Kingdom Of

Saudi Arabia

Nomination Document for the Inscription on the UNESCO

WORLD Heritage List

2- Qal'at (Fort) al-Bahrain, Kingdom of Bahrain

Nomination Document for the Inscription on the UNESCO

WORLD Heritage List

3- Qal'at Bahla (Fort), Sultanate of Oman

Nomination Document for the Inscription on the UNESCO

WORLD Heritage List

4- Qal'at Al Jahili, al-'Ain, Abu Dhabi, UAE

Nomination Document for the Inscription on the UNESCO

WORLD Heritage List

5- Qal'at al-Zubarah, al-Zubarah, Qatar

Nomination Document for the Inscription on the UNESCO

WORLD Heritage List

6. The Boston Foundation

www.tbf.org/indicators2004/culturallife

7. The Boston Foundation

www.tbf.org/SelectSurvey/TakeSurvey.asp?SurveyID=3M09p4K

$\underline{\mathrm{Lm} 753 \mathrm{G}}$

8. American Planning Association

www.planning.org/research/arts/briefingpapers/character.htm 